\title{
Wendell Berry's Farmer: Balancing 'the Natural' with 'the Cultural'?
}

\section{Mark Brown}

University of Oslo

\begin{abstract}
In this article I take as my starting point the call to explore ways of relating to nature through a discussion of the poet and farmer Wendell Berry's idea of community. Exploring the ethics of ecological community, I suggest that they parallel the Emersonian conception of self reliance. I proceed with an explication of some of the relationships that exist within Berry's community with nature, examining attitudes to both wild nature and to the soil. The living out of these relationships is intended to invoke in Berry's self-reliant individual the requisite selfrestraint to assure the community's sustainable existence. I observe that the level of self-restraint demanded by acquiescence to the harsh ecological strictures of nature can be moderated by mankind's introduction of cultural tools into the landscape. However, my reading of Berry's community with nature is that his vision is supported exclusively by examples taken from the farming landscape which he knows best. I conclude that more development is needed on the vital question of how his community relates to the utilization of technology, and to question the relevance of this vision of man in the landscape to an overwhelmingly urban society.
\end{abstract}

Keywords: Wendell Berry - Emerson - self reliance - individual - community - nature - landscape-technology-farming.

It is surely uncontroversial to claim that mankind, or at least, that part of mankind which considers itself to be part of the 'developed' world, urgently needs to rethink its relationship with the natural world in order to mitigate the worst consequences of the environmental changes that it has brought about. I choose to conceptualize this relationship simplistically in terms of finding a balance between 'the natural' and 'the cultural'. The balance will be manifested in cultural landscapes, whose characteristic is that human usage of the land and its resources is compatible with the health of the biosphere. Wendell 
Berry's articulation of an ethic of environmental self-restraint stands as a significant exploration of how to live out the balance between 'the natural' and 'the cultural' in the farming landscape of rural Kentucky.

Wendell Berry is a farmer, poet and essayist in that order. He grew up in Kentucky and received his education there, pursued a successful academic career at New York University, and then returned to Kentucky, first as an academic and subsequently as a farmer and a writer. His hill farm is run organically using very little mechanized equipment and he has drawn heavily on his experience running the farm as well as his childhood memories of post-war rural life in Kentucky in writing of a large number of books of poetry, fiction and nonfiction. Although several of these books are cited in this article the primary source used is The Unsettling of America, ${ }^{\prime}$ a polemic against the industrialization of American agriculture.

In his work, Berry believes that the attainment of a balanced cultural landscape rests in large part on the relationship between the individual and community. In my reading Berry's morally engaged individual looks very similar to the picture of individualism Emerson draws in "Self Reliance." I shall explore some of the relationships she experiences in this community before finally considering how Berry's community attempts to strike a balance between 'the natural' and 'the cultural'.

\section{Berry's community with nature and the ethics of place}

In Wendell Berry's community “all who are living as neighbors here, human and plant and animal are part of one another." 3 Berry's community is more than a congregation of human beings. It includes plant and animal life. ${ }^{4}$ It must also have a particular spatial location and Berry's individual needs to commit herself to this place; to the landscape, and to its occupants: "human

1. Wendell Berry, The Unsettling of America, (San Francisco: Sierra Club, 1977).

2. Ralph Waldo Emerson, "Self-Reliance" in The Heart of Emerson's Essays, edited by Bliss Perry (Boston: Houghton Mifflin Company, 1993), 96-122.

3. Berry, The Unsettling of America, 22.

4. Berry's explanation of what a community consists of is very similar to the introduction to "Community, Biological" contained in Encyclopeedia Britannica: "A biological, or natural, community consists of all the organisms that live together in a given environment and, in various ways, affect one another." Encyclopadia Britannica, 15 th edition, s.v. "Community, Biological". 
and plant and animal." ${ }^{5}$ She has nothing to gain by roaming the continent in pursuit of a dream or 'starting over out west'. Here, in an autobiographical essay, he explains his difficult decision to forsake a successful career in New York City and return to his home in Henry County, Kentucky: "Hadn't I achieved what had become one of the almost traditional goals of American writers? I had reached the greatest city in the nation; I had a good job; I was

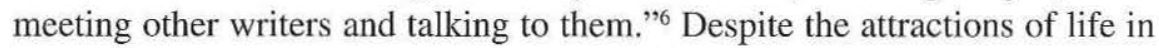
New York, Berry made the decision to withdraw from the city. Thus began a process that soon took him back to a farm in Henry County and here he began to learn about belonging; "[a]nd I began to understand that so long as I did not know the place fully, or even adequately, I belonged to it partially. That summer I began to see, however dimly, that one of my ambitions ... was to belong fully to this place."7

Through commitment to place Berry's individual develops the virtue of self-restraint. ${ }^{8}$ The experience of living in Berry's community evokes selfrestraint. This is not the same as saying that it causes the individual's selfrestraint. It is to be hoped that this experience of community makes the individual's exercise of self-restraint easier than it would be in an atomistic society that encourages an ethic of self-interestedness. But there still exists the possibility that she may not respond to the community's evocation of ecological restraint: "Community discipline imposes upon our personal behavior an ecological question: What is the effect, on our neighbors and on our place in the world, of what we do? It is aware that all behavior is social." 9 When Berry speaks of "community as a discipline" it is with the meaning of the individual choosing to become a disciple who wishes to learn. This

\section{Berry, The Unsettling of America, 22.}

6. Wendell Berry, "A Native Hill" in The Long-Legged House, (New York: Harcourt Brace Jovanovich, 1969), 173-174.

7. Ibid., 150 .

8. In contrast, exploitation is the vice that is unconsciously acquired by the mobile. For, as Berry says in Unsettling of America, 52: "When people do not live where they work, they do not feel the effects of what they do (...) The people responsible for strip-mining, clear-cutting of forests, and other ruinations do not live where their senses will be offended or their homes or livelihoods or lives immediately threatened by the consequences." The mobile exploit the land and they exploit other people. But, says Berry, we cannot live as exploiters without exploiting ourselves. One way or the other the result is the exploitation of our bodies. In Berry's community with the natural everyone and everything is drawn together in a web of interconnectedness: "... it is impossible, ultimately, to preserve ourselves apart from our willingness to preserve other creatures or to respect and care for ourselves except as we respect and care for other creatures ..." (123).

9. Wendell Berry, A Continuous Harmony: Essays Cultural and Agricultural, (San Diego: Harcourt Brace \& Company, 1970), 156. 
is different from a typical form of communitarianism in which its leaders rank the rights of the community over the rights of individuals. In this form of social organization individuals must accept externally-imposed limits set by the community, and the stick used to cajole and threaten the dissenters is religion or ideology. Therefore although Berry's vision has a vital role for community it is not communitarian. Rather, as I shall now argue, Berry's individual-in-community really shares much in common with Emerson's self-reliant individual.

A study of "Self-Reliance" reveals that acceptance of the sense of place is one common factor between Berry and Emerson. It is a recurrent theme throughout Emerson's essay: "Accept the place the divine providence has found for you, the society of your contemporaries (...) let us not rove; let us sit at home with the cause." ${ }^{10}$ Emerson's individual limits himself just as we have seen Berry advocate. We cannot achieve anything by traveling: "It is a fool's paradise." "' But Emerson's self-reliant individual is not someone we are accustomed to associate with community. He stands apart from community, capable of detached evaluation and the exercise of self-determination, and he seeks nature, for it is through nature that he can gain his moral consciousness:

[E]very natural process is a version of a moral sentence. The moral law lies at the centre of nature and radiates to the circumference ... What is a farm but a mute gospel? ... Nor can it be doubted that this moral sentiment which thus scents the air, grows in the grain, and impregnates the waters of the world, is caught by man and sinks into his soul. ${ }^{12}$

By comparison, Berry's individual sees all around her own immersion in, and connectivity with, her community. Berry's community consists of both limited human society and also the natural world around the individual, the same nature in which Emerson's individual seeks refuge from society as a ground for his moral consciousness. It includes the farm that Emerson refers to, the grain and the water.

One apparent difference however, is that Emerson's individual avoids the company of other people. Emerson appears to perceive man's relationship with his social surroundings as one which can only lead to division and breakdown. A man must make up his own mind, but society expects certain

10. Emerson, "Self-Reliance" in The Heart of Emerson's Essays, 97 and 111.

11. Ibid., 117.

12. Ibid., 34-35. 
opinions from him. So he has no choice but to reject the society of mankind, even his family: "I shun father and mother and wife and brother when my genius calls me. I would write on the door-post, Whim."13 But despite this initial antagonism towards society, Emerson also sees that it is possible to live within one's community, among men, and yet still be one's own man. It is possible to accept other realities in the community while maintaining one's own truth. Indeed, Emerson concludes that this is a mark of greatness:

It is easy in the world to live after the world's opinion; it is easy in solitude to live after our own; but the great man is he who in the midst of the crowd keeps with perfect sweetness the independence of solitude. ${ }^{14}$

My reading of "Self-Reliance" then, is not that community has certain (moral) expectations and that in order to be self-reliant individuals we are obliged to reject our community. Rather, it is that community has certain (moral) expectations and if we want to be truly self-reliant we are obliged to remain within that community as its internal critics. One might say that Emerson's selfreliant individual belongs in Berry's community. Berry's community exists to provide a discipline that, hopefully, evokes the individual's powers of selfrestraint:

[But] truly it demands something godlike in him who has cast off the common motives of humanity and has ventured to trust himself for a task master. High be his heart, faithful his will, clear his sight, that he may in good earnest be doctrine, society, law, to himself, that a simple purpose may be to him as strong as iron necessity is to others. ${ }^{15}$

These are similar to the qualities that Berry seeks in his individual:

A person can free himself of a bondage that has been imposed on him only by accepting another bondage that he has chosen. A man who would not be the slave of other men must be the master of himself. ${ }^{16}$

Both Emerson and Berry agree that we cannot safely escape from sociallyimposed limitations other than by choosing to replace them with self-imposed limitations. Our freedom from external limits cannot be achieved either by breaking those limits or by withdrawal into a wilderness where, we hope,

\author{
13. Ibid., 100. \\ 14. Ibid., 101. \\ 15. Ibid., 113. \\ 16. Berry, A Continuous Harmony, 129.
}


none exist. The way to freedom lies in learning the limits and ecologies of our landscapes and finding the strength of will to live within them. Berry advocates neither communitarianism nor individualism. In both of these ideologies there is a need for an external discipline to be exercised over the individual. In communitarianism the community meets that need and in individualism it is a much larger entity: society in the form of the state. What Berry stands for, and what Emerson's "Self-Reliance" advocates, is at variance with the liberal definition of individualism.

Sacvan Bercovitch has explored the meaning of individualism in the context of nineteenth century American culture. ${ }^{17}$ He notes the universally negative meaning which individualism had at the beginning of the nineteenth century: "the vice of the age ... ruthless exploitation ... spiritual rootlessness ... social atomization." ${ }^{18}$ He goes on to show how Jacksonians redefined it and how "throughout the 1840s, in what amounted to a full scale American counter-attack against European critics, 'individualism' was unofficially but effectively redefined as 'the last order' and 'highest reach of civilization..." 19 Did Emerson accept the new meaning of individualism? While there are different opinions on this question, ${ }^{20}$ Bercovitch thinks not:

Individualism is for [Jacksonians] the natural condition of a new nation-state which is bringing to fruition, institutionally, the "great progressive movement" ascending from the "state of savage individualism to that of an individualism more elevated, moral, and

17. Sacvan Bercovitch, The Rites of Assent: Transformations in the Symbolic Construction of America, (New York: Routledge, 1993), 307-352. All the citations I have used are contained in the one essay, "Emerson, Individualism, and Liberal Dissent."

18. Bercovitch, The Rites of Assent, 309. According to Cyrus K. Patel, the term was originally coined by the French. Individualisme coined in the 1820 's implied a critique of Enlightenment thought. Both proponents and adversaries of enlightenment thinking "were appalled at the elevation of the individual." He also provides a quote from de Tocqueville who defined individualism as "a calm and considered feeling which disposes each citizen to isolate himself from the mass of his fellows and withdraw into the circle of family and friends." Patel, Cyrus, "Emersonian Strategies: Negative Liberty, Self-Reliance", Nineteenth Century Literature 48:4, (March, 1994): 445.

19. Bercovitch, The Rites of Assent, 312-313.

20. For many years received opinion among Emerson scholars was that there was Early Emerson and Late Emerson. The former, in essays such as "The American Scholar" (1837) and "Self-Reliance" (1841), put forward his vision of American High Romanticism, and in rejecting society's relevance, rejected individualism too. The latter, exemplified by "Conduct of Life" (1860) had recognised the necessity of external discipline of the individual and thereby endorsed Jacksonian Individualism. However, John Peacock has argued that Emerson saw the necessity of society's external control right from the start, and that his writing reveals this. Peacock, John, "Self-Reliance and Corporate Destiny: Emerson's Dialectic of Culture". ESQ: A Journal of the American Renaissance 29:2, (1983): 59-72. 
refined." For Emerson, on the contrary, individualism centers on the independent Self. Progress is a function of self-reliance working against the ubiquitous conspiracies of society. ${ }^{21}$

Since the Jacksonians have won acceptance for their liberal definition of individualism, it seems sensible to admit that individualism is the wrong term to describe Emerson's individual.

The proper term for [Emerson's] outlook is individuality, the belief in the absolute integrity, spiritual primacy, and inviolable sanctity of the self ... It is worth stressing that individuality in its modern sense is neither American nor liberal nor democratic. It is European, radical, and antibourgeois ... deriv[ing] first from Christianity, and then, in its modern genesis, as a post-Renaissance, post-Reformation ideal of self-realization, from Germany, France, and England, where it was developed in explicit antagonism to the perceived defects of systemic individualism. ${ }^{22}$

This is the essence of Berry's view. His individual is called upon to see that personal limits to freedom of action that are necessary if community with nature is to be achieved and sustained. Berry's morally engaged individual is invited to choose these limits and accept them as her own. Berry's community with nature evokes powers of self-restraint and commitment to limits as well as a commitment to place. But it is vital that there is a choice, for as Berry observes: "Where there is no possibility of choice, there is no possibility of faith. One who returns home - to one's marriage and household and place in the world - desiring anew what was previously chosen, is neither the world's stranger nor its prisoner, but is at once in place and free."23

Only Berry's individual herself can accomplish this task. But what an awesome task it is; "truly it demands something godlike" in her to embrace the truth of the world. This god-like quality, a "simple purpose" which is for her "as iron necessity," is to "accept the place the divine providence has found" for her in the world. ${ }^{24}$ In this first section I have sketched out the contours of

21. Bercovitch, The Rites of Assent, 313.

22. Ibid., 314-315.

23. Berry, The Unsettling of America, 131. For Berry, home and place are repeatedly chosen and their truth authenticated. Man yields a place to the wilderness in order "to serve as instruction, example, refuge (131), but he always chooses to return to his place. This aspect of Berry is discussed by Mark Shadle, "Wandering and Return in Wendell Berry" in Wendell Berry, edited by Paul Merchant, (Lewiston ID: Confluence, 1991).

24. Emerson, "Self-Reliance" in The Heart of Emerson's Essays, 97. 
a landscape populated by Berry's iron-willed Emersonian individual. In the next section I will explore how she is expected to be able to summon up the willpower to live in her place.

\section{The Ecological Ethics of Community with Nature}

Berry conceptualizes his community as one living organism: "all who are living as neighbors here, human and plant and animal are part of one another." 25 Superficially, we may seem to be just neighbors. But Berry insists that our neighborly relations run much deeper, to the extent that we are "part of one another." His conviction, however, is more intuitive than rational and as he returns to his point he admits that he has been "groping for connections that I think are indissoluble, though obscured by modern ambitions - between the spirit and the body, the body and other bodies, the body and the earth."26 I would like to dwell on his aside that these connections are "obscured by modern ambitions" because I think it is an extremely important defense of his rural vision of community.

Surely one of the crucial ecological questions that we ought to be asking ourselves is what are the effects of what we do? Yet the answer to this simple question is obscured by the enormous complexities of our "modern ambitions." We live in a fog of ignorance as to the environmental consequences of many of our actions. Berry's community with nature may justifiably be criticized for offering a vision that is a wholly unrealistic political ideal. But he must be given credit for insisting that we, as individuals, need to experience the connections between ourselves and the other members of the biosphere and to know the effects on them of our actions. ${ }^{27}$

Berry's individual recognizes this and has taken her anthropocentric place at center stage of the eco-system that is her community with nature. She has

\section{Berry, The Unsettling of America, 22.}

26. Ibid., 123.

27. An ecologist makes the same point in this way: "Almost every species is dependent upon other species (...) The loss of one species will invariably cause the extinction of others. The importance and extent of such cascade effects ... are almost entirely uninvestigated." Tormod V. Burkey, "Ecological Principles for Natural Habitats Management" Unpublished paper prepared for the World Bank, 7. Hereafter cited as Burkey. Tormod Burkey is a postdoctoral fellow at the University of Oslo, Centre for Development and the Environment, Sognsveien 68, PO Box 1116 Blindern, N-0317 Oslo, Norway. 
taken upon herself the burden of responsibility for the community of nature, a stewardship of even the parts of nature that might appear to be useless and unprofitable: a responsibility for the wild. ${ }^{28}$ Berry's individual is often presented as a farmer, and according to Berry a good farmer recognizes that sustainable stewardship of the community depends upon her adherence to the principle of diversity, a notion ignored by monoculture-driven agribusiness. How can she learn what mix is most appropriate, most sustainable, for a particular place? Sir Albert Howard's advice was to study the forest for only

the forest, as Howard pointed out, "manures itself" and is therefore self-renewing; it has achieved "that correct relation between the processes of growth and the processes of decay that is the first principle of successful agriculture." 29

Howard was suggesting to the good farmer that she should retain the wildness, by which he meant the naturally occurring indigenous plant and animal life, within the boundaries of the farm. In so doing the farmer would have a trustworthy guide and yardstick of the health of the soil. Rather than trying to push the limits of the farm onto soil that is not suitable, the good farmer should restrain herself and instead incorporate this marginal land into the structure of the farm. Here Berry describes just such an approach to farming in the agriculture of Peruvian hill farmers:

But the sophistication and durability of Andean agriculture cannot be fully appreciated until one has understood the way it utilizes - indeed depends on - its margins. The fifty potato varieties used in Uchucmarca are not a stable quantity, but rather a sort of genetic vocabulary in a state of continuous revision. Professor Brush ${ }^{30}$ says that "new varieties are constantly being created through cross-pollination between cultivated, wild and semi-domesticated (weedy) species..." Thus if an Andean farmer loses a crop because of an extremity of the weather or an infestation of insects or disease, he may find a plant of a new variety that has survived the calamity and produced in spite of it. ${ }^{31}$

28. I use the terms wild and wildness to denote a quality of the cultural landscape. Just as we now recognise that what we call wilderness bears the signs of cultural intervention, so is it also possible for a cultural landscape to incorporate wildness.

29. Berry, "Discipline and Hope" in A Continuous Harmony, 97-98.

30. Berry is referring to Professor Stephen B. Brush of the Department of Anthropology at the College of William and Mary. He quotes from an unpublished paper by Brush; a study of a village in a valley in northern Peru.

31. Berry, The Unsettling of America, 178. This observation of robustness is conditionally supported by ecologists: "Some experiments suggest that species rich systems may be less vulnerable to perturbations and may return more rapidly to the predisturbance state than relatively depauperate systems" (Burkey, 8). 
Thus Berry's healthy community will be tolerant of its margins - human, plant and animal - and this will enable it "to put dissent and divergence to use, to turn a curious eye to the margins..." ${ }^{32}$ Nature, then, is incorporated within Berry's broad vision of community, and the individual, recognizing her connections with people, animals, plants and even the margins of wildness, is called upon to exercise the self-restraint that keeps the community and thus, herself, in a condition of sustainable health.

Berry also claims a connection between "the body and the earth." Not only do we have a relationship of responsible dependence with the humans, animals and plants within the community, we are also connected to the soil on which we live. And of all our dependencies, this one is the most fundamental relationship: “... as we and our land are part of one another, so all who are living as neighbors here, human and plant and animal are part of one another." ${ }^{33}$ It is our relationship to the land where we live and work that gives us the connectivity we need with our neighbors: human, plant and animal: "The world that environs us, that is around us, is also within us. We are made of it; we eat, drink, and breathe it; it is bone of our bone and flesh of our flesh." ${ }^{34}$ We come from the earth and we return to the earth, and while we are alive the earth is part of us:

The soil is the great connector of lives, the source and destination of all. It is the healer and restorer and resurrector, by which disease passes into health, age into youth, death into life. Without proper care for it we can have no community, because without proper care for it we can have no life. ${ }^{35}$

We are part of the wheel of life and through our births, lives and deaths, we keep it turning. ${ }^{36}$ As the soil has become us, so have our ancestors become the

32. Ibid., 179.

33. Ibid., 22.

34. Wendell Berry, "Conservation is Good Work" in Sex Economy Freedom \& Community, (New York: Pantheon Books, 1992), 34.

35. Berry, The Unsettling of America, 86. The composition of soil can be divided into two main categories. There are the products of the breakdown of rocks: the inorganic matter. Then there is humus, the dark brown or black substance which results from the slow decomposition and oxidization of organic matter. It is humus that provides most of the life giving nutrients that plants need; "humus. See HOMO." "human. See HOMO." "homo...generic "man": OL [Old Latin] hemo: "the earthy one, the earth-born, from L[Latin] humus, earth, (soil, ground), loc. humi, on the ground" (ORIGINS 292). Not only does this reference demonstrate the common root of human and humus. It also notes the common root with humility, a term introduced by Berry in talking of our proper attitude towards the Creation.

36. Berry freely acknowledges that the term is Sir Albert Howard's (The Unsettling of America, 82). Howard 
soil. Thus in Berry's community we have people, plants and animals, and the soil brings us all together. It is our common ground of experience.

However, experience of this interconnectedness, although a necessary prerequisite to action, is not sufficient. Having experience of the bonds, we need the willpower to demonstrate responsibility. "There is, in practice, no such thing as autonomy. Practically, there is only a distinction between responsible and irresponsible dependence." ${ }^{37}$ What degree of self-restraint need Berry's individual exercise in order to maintain the health of the wider community? William Cronon describes how the Native American Indian identification with community was so strong as to lead to self-sacrifice rather than just self-restraint. What is particularly interesting about his example of the Native Americans of northern New England is that their understanding of community is the same as Berry's:

Northern Indians accepted as a matter of course that the months of February and March, when the animals they hunted were lean and relatively scarce, would be times of little food ... Consciously choosing hunger, rather than working harder in the leisurely times of summer, seemed a fool's decision ... One effect of that choice, however, was to hold northern Indians to low population densities ... [and] ... By keeping population densities low, the food scarcities of winter guaranteed the abundance of spring, and contributed to the overall stability of human relationships to the ecosystem. ${ }^{38}$

Cronon's description of the self-sacrifice of the Indians may seem to be eminently sensible within the context of the larger community. But it is narrated from the comfort of an academic's sabbatical semester, and we should focus on his description of what living within natural ecosystems has sometimes required of men; we should be skeptical that the reconceptualization of our relationship with community might be capable of delivering the level

was a British agricultural scientist who published several books in the 1940s. Berry refers to An Agricultural Testament and The Soil and Health, and says that Howard introduced the term as a description of the process of birth, growth, maturity, death and decay. It appears that he applied a completely new interpretation to an existing phrase which had an unrelated meaning. The OED lists wheel of life, but refers to its usage in connection with zoetrope: "A mechanical toy or optical instrument consisting of a cylinder open at the top, with a series of slits in the circumference, and a series of figures representing successive positions of a moving object arranged along the inner surface, which when viewed through the slits while the cylinder is in rapid rotation produce the impression of actual movement of the object. Also called wheel of life." According to the OED, the term was first used, describing the zoetrope, in 1869.

37. Berry, The Unsettling of America, 111.

38. William Cronon, Changes in the Land: Indians, Colonists and The Ecology of New England, (New York: Hill and Wang, 1983), 40-41. 
of commitment, willpower, or abnegation that is presented here. Thankfully, Cronon's account is taken from New England, a landscape though evidently not a virgin wilderness was, nonetheless, considerably wilder than the cultural landscape in which Wendell Berry's individuals learn community ethics. The recognition of interconnectedness is the same for Berry's landscape as it is for the $17^{\text {th }}$ century American Indians, as is the need for all within the community to thrive:

[I]t is impossible, ultimately, to preserve ourselves apart from our willingness to preserve other creatures, or to respect and care for ourselves except as we respect and care for other creatures. ${ }^{39}$

The American Indians conceptualized themselves as part of an ecological network over which they exerted a minimum of stewardship whereas we have seen that Berry's individual has assumed a responsibility of stewardship. One of the privileges accruing from the power which she has assumed over her community is that of easing the harsh material conditions of life that Cronon's Indians seemed willing to accept. To help her she has a plethora of tools made available to her by the ingenuity of western technology. But which ones can she safely employ without compromising the sustainability of her community? In the short, final section of this paper I will present Berry's rather sketchy view on the enormously difficult question of the extent to which mankind should permit itself to modify the 'natural' with the 'cultural.'

\section{How much of the 'Cultural' in Berry's Community with Nature?}

How does Berry propose that we manage the trade-off between the enormous benefits offered by technology and the enormous environmental challenges that seem to be a part of the package? To what extent does Berry's individual allow herself to interfere with nature? What is her attitude towards technology, the tools which give her such power to interfere with nature's processes? Berry clearly believes that technology has advanced beyond what he considers to be good for us: 
At some point in history the balance between life and machinery was overthrown. I think this began to happen when people began to desire long-term stores or supplies of energy ... and when machines ceased to enhance or elaborate skill and began to replace it. $^{40}$

And it is this concern for a balance between life and machinery which informs his criterion for the evaluation of technology: “... the living part of our technology," by which he means the human or animal element, "should not be devalued or overpowered by the mechanical." ${ }^{41}$ He applies this principle within the field he knows best: agriculture, and the suggestions he has made, some of which are now over twenty years old, are enjoying increasing recognition and support from the agricultural establishment. But his good examples are only from agriculture. Berry does not address the use of technology in, for example, healthcare, an area in which lives that would once have been lost are increasingly being saved. This is a serious weakness in his vision and he as much as concedes this in his stated wish to start a national dialogue on the value of technology:

[W] e must address ourselves seriously, and not a little fearfully, to the problem of human scale. What is it? How do we stay within it? What sort of technology enhances our humanity? What sort reduces it? $?^{42}$

Given Berry's critique of the industrialization of agriculture it is tempting to dismiss him as a Luddite. But the dialogue which he is trying to initiate is not anti-technology. Berry's wish is not to dispose of technology. Rather, it is to rethink the objectives for its use. He is asking for the re-institution of smallscale technology which enhances the individual's or the community's selfreliance. One example of this is contained in his short essay "A Good Scythe" in which he compares the merits of a gasoline-powered edge cutter, which he had purchased from Sears Roebuck, with the hand scythe that he bought to replace it. ${ }^{43}$ Berry lists nine practical advantages of the hand scythe and then adds two further differences which he considers to be just as important and which answer to his quest for technology which enhances our humanity. Here is one of them:

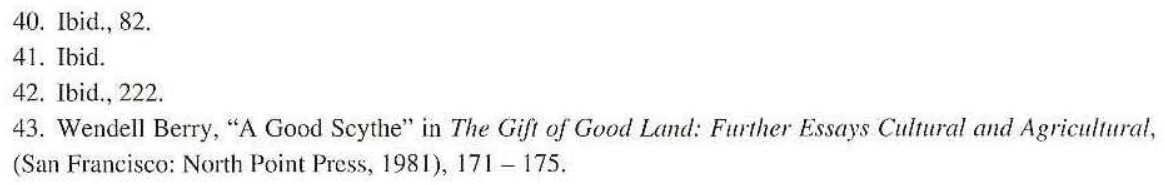


The first is that I never took the least pleasure in using the power scythe, whereas in using the Marugg scythe, whatever the weather and however difficult the cutting, I always work with the pleasure that one invariably gets from using a good tool. And because it is not motor driven and is quiet and odorless, the Marugg scythe also allows the pleasure of awareness of what is going on around you as you work. ${ }^{44}$

In another essay, "Energy in Agriculture," Berry argues that energy "is a powerful social and cultural influence. The kind and quantity of the energy we use determine the kind and quality of the life we live." ${ }^{45}$ Again, he argues that agriculture's shift from solar, biologically-derived power to machinederived fossil fuel power has led to our wasting human energy and ability as the machines have taken over.

Berry's call here resembles E. F. Schumacher's Intermediate Technology, but in discussing its application, Schumacher was "concerned here exclusively with the problem of helping the people in the non-modern sector," and had nothing to say about the use of such technology in an industrialized country such as the USA. ${ }^{46}$ It seems, on the basis of my readings of Berry, that all his examples come from the rural landscape that he knows so well, and that he does not address the condition of the vast majority of his countrymen. In my reading of Berry therefore, the crucial question of how we relate to technology is raised, but remains largely unanswered, just as the relevance of his vision to modern, urban America also leaves a question mark.

\section{Works Cited}

Bercovitch, Sacvan. The Rites of Assent: transformations in the symbolic construction of America. New York: Routledge, 1993.

Berry, Wendell. A Continuous Harmony: Essays Cultural and Agricultural. San Diego: Harcourt Brace \& Company, 1970.

- The Gift of Good Land: Further Essays Cultural and Agricultural. San Francisco: North Point Press, 1981.

- The Long-Legged House. New York: Harcourt Brace Jovanovich, 1969.

- Sex, Economy, Freedom, \& Community. New York: Pantheon Books, 1992.

- The Unsettling of America. San Francisco: Sierra Club, 1977.

44. Ibid., 174.

45. Berry, "Energy in Agriculture" in The Gift of Good Land, 125-133.

46. Ernst Schumacher, Small is Beautiful: A Study of Economics as if People Mattered, (London: Sphere books Ltd, 1974), 143. 
Brush, Stephen B. (Department of Anthropology at the College of William and Mary). Unpublished paper. "A Study of a Village in a Valley in Northern Peru."

Burkey, Tormod V. "Ecological Principles for Natural Habitats Management." Unpublished paper prepared for the World Bank.

Cronon, William. Changes in the Land: Indians, Colonists and the Ecology of New England. New York: Hill and Wang, 1983.

Emerson, Ralph Waldo. The Heart of Emerson's Essays, edited by Bliss Perry. Boston: Houghton Mifflin Company, 1993.

Howard, Albert. An Agricultural Testament. London: Oxford University Press, 1943.

Patel, Cyrus K. "Emersonian Strategies: Negative Liberty, Self-Reliance". Nineteenth Century Literature 48:4, (March, 1994): 445.

Peacock, John. "Self-Reliance and Corporate Destiny: Emerson's Dialectic of Culture". ESQ: A Journal of the American Renaissance 29:2, (1983): 59-72.

Shadle, Mark. "Wandering and Return in Wendell Berry." In Wendell Berry edited by Paul Merchant. Lewiston ID: Confluence, 1991.

Schumacher, Ernst. Small is Beautiful: A Study of Economics as if People Mattered. London: Sphere books Ltd, 1974. 